\title{
Sediment-water oxygen, ammonium and soluble reactive phosphorus fluxes in a turbid freshwater estuary (Curonian lagoon, Lithuania): evidences of benthic microalgal activity
}

\author{
Mindaugas ZILIUS, ${ }^{1}$ Darius DAUNYS, ${ }^{1}$ Jolita PETKUVIENE, ${ }^{1}$ Marco BARTOLI ${ }^{2 *}$ \\ ${ }^{1}$ Coastal Planning and Research Institute, Klaipeda University, 92294 Klaipeda, Lithuania; ${ }^{2}$ Department of Environmental Sciences, \\ Parma University, 43124 Parma, Italy \\ *Corresponding author: marco.bartoli@unipr.it
}

\begin{abstract}
Seasonal measurements of total and diffusive benthic fluxes were performed during the ice-free period in the Curonian Lagoon (Lithuania). This mostly freshwater hypertrophic basin exhibits wide seasonal variations of water temperature $\left(1-22^{\circ} \mathrm{C}\right)$ and inorganic nitrogen availability and it is subjected to dramatic blooms of diatoms and cyanobacteria $\left(>100 \mu \mathrm{g}\right.$ chl a $\left.L^{-1}\right)$. In this shallow lagoon, nutrient exchanges at the sediment-water interface and the regulating factors have been poorly explored. Overall aim of the present work is to demonstrate that the activity of benthic microalgae, generally neglected in turbid systems, can be a relevant regulator of sedimentary processes. To this purpose, light and dark fluxes of oxygen, ammonium and soluble reactive phosphorus were measured seasonally by intact core laboratory incubation and diffusive fluxes were calculated from sediment profiles. We investigated sandy sediments that were collected from the central area lagoon, that is representative of the most of the shallower lagoon area.

Oxygen and ammonium fluxes were significantly different under light and dark incubations, suggesting an active role of benthic microalgae at the sediment-water interface. In the light net oxygen production was measured in three out of four samplings, with July as only exception, and ammonium was retained within sediments. In the dark sediment respiration displayed a temperature-dependent pattern while ammonium efflux increased from March to October. Fluxes of reactive phosphorus varied significantly with sampling seasons but were less affected by the incubation condition. Diffusive fluxes peaked in July, where highest concentration gradients at the interface and theoretical efflux of ammonium and reactive phosphorous were calculated. The marked differences between diffusive and total nutrient fluxes are probably due to photosynthetic activity by benthic microalgae, and thus oxygen production, enhancement of aerobic processes and net solute uptake at the sediment-water interface. Our findings support the hypothesis that even in highly turbid systems benthic microalgae can have a relevant role as filters for regenerated nutrients and as regulators of benthic processes.
\end{abstract}

Key words: sediment, oxygen, nutrients, benthic fluxes, benthic microalgae, Curonian lagoon.

Received: November 2011. Accepted: June 2012.

\section{INTRODUCTION}

Nutrients of terrestrial origin undergo a series of biogeochemical transformations when they pass through transitions zones such as estuaries and lagoons (Wollast, 1983; Seitzinger, 1988; Ogilvie et al., 1997). They can be incorporated into benthic and pelagic primary producers, grazed by herbivores and rapidly recycled to the water column or they can be retained in surface sediments as buried organic matter or co-precipitated with other elements or as organic aggregates (Howarth, 1988; Conley and Malone, 1992; Cowan and Boynton, 1996; Grossart et al., 1997; Conley et al., 2009). The coupling of these processes can significantly delay the delivery of nutrients to coastal areas, but sudden release and export of temporary trapped elements by diffusion, bioturbation or resuspension processes can also occur (Jensen et al., 1990; Jensen et al., 1995; Pelegrí and Blackburn, 1995).

In highly productive shallow coastal areas the equilibrium between pelagic and benthic primary production is generally controlled by turbidity and light penetration (Sundbäck et al., 2004; Gerbersdorf et al., 2005). At sites exhibiting elevated rates of planktonic primary production, pulse inputs of labile organic matter to the sediment follow each bloom and crash event; such inputs fuel microbial, meio- and macrofauna activity which in turn regulates the efflux of dissolved nutrients back to the water column (Callender and Hammond, 1982; Cowan and Boynton, 1996; Kristensen, 2000). Inputs of labile organic matter generally turn surface sediment fluffy, with limited retention capacity for nutrients, due to a combination of reduced conditions, saturated geochemical buffers, enhanced microbial activity and strong pore water to bottom water chemical gradients (Viaroli et al., 1996). On the contrary, sites with autotrophic sediments generally retain nutrients via uptake at the sediment-water interface both from the water column and from pore water (Sundbäck et al., 2000, 2004; Bartoli et al., 2003). Moreover, photosynthetic oxygen production by algal cells at the interface 
oxidizes surface sediments, with important biogeochemical implications as phosphorus (P) retention and, where nitrogen $(\mathrm{N})$ is not limiting, simultaneous stimulation of nitrification (due to enhanced oxygen availability) and denitrification (due to diffusion of produced nitrate to the anoxic zone) (Seitzinger, 1988; Risgaard-Petersen et al., 1994; Ogilvie et al., 1997; Sundbäck et al., 2000).

The evaluation of benthic primary production and related ecosystemic functions in turbid shallow coastal areas has been seldom addressed in the literature, despite its potential relevance. There are in fact evidences that benthic microalgae can remain viable even if they are not exposed to light for long periods, that they are capable of photosynthesis at very low light levels and that they can start photosynthesizing when the water column becomes more transparent, for example during post bloom periods (Sundbäck and Graneli, 1988; Sundbäck et al., 2004). Even if limited in time, activity by benthic microalgae could contribute to the recovery of organic matter impacted sediments; for example, Larson and Sundbäck (2008) have demonstrated that ecosystemic functions as sediment oxygenation, associated with benthic diatoms, are rapidly re-established after short term hypoxic events.

Our main question in this study was to investigate whether benthic photosynthetic activity affected significantly nutrient fluxes at the sediment-water interface of a turbid shallow lagoon. To answer this question we measured seasonal oxygen, ammonium and soluble reactive phosphorus exchanges at the sediment-water interface by means of light and dark incubations of intact sediment cores and we calculated diffusive fluxes from pore water profiles. In the considered hypereutrophic system, where bioturbation has a minor relevance (Daunys, 2001; Zilius et al., 2012), we hypothesized that differences between light and dark fluxes and between measured and calculated benthic exchanges are due to the activity of benthic microalgae.

This study was realized in the Curonian Lagoon (southeastern part of the Baltic Sea), a dystrophic boreal system that suffers frequent events of plankton bloom and collapse (Jokšas et al., 1998; Pilkaityte and Razinkovas, 2006, 2007). In this turbid transitional area the pelagic primary production drives a large fraction of the whole lagoon production, but there are moments as post blooms periods during which light penetration in the shallow water can allow photosynthesis by benthic microalgae.

\section{METHODS}

\section{Study site}

The Curonian Lagoon is a large freshwater estuary, the largest in Europe, with a surface of about $1500 \mathrm{~km}^{2}$ (Fig. 1). The study area lays in the northern Lithuanian part, characterized by relatively low water residence time $(<40$ days on average), shallow depth, averaging $1.7 \mathrm{~m}$, and a high bottom shear stress (Ferrarin et al., 2008) which prevents excess accumulation of organic material. During calm weather conditions, flocculent layers of freshly deposited phytoplankton can develop on surface sediments. Benthic primary production is generally limited by low light availability at the sediment surface, due to wind-driven sediment resuspension, turbidity and phytoplankton blooms (Razinkovas and Pilkaityte, 2002).

Although shallow depths and windy weather determine water column mixing and unstable stratification (Pustelnikovas, 1998), mean dissolved oxygen saturation (measured at daylight) in water column is typically below $100 \%$ (Zilius et al., 2012). Nutrient dynamics are strongly affected by seasonal inputs from the Nemunas river with spring peaks, coinciding with snow melt in the catchment area, and summer minimum, due to scarce precipitations and algal uptake (Gasiūnaite, 2000; Dailidienè and Davulienè, 2007, 2008). Water and sediment samplings were carried out at four dates: on 16/03/2009, 20/05/2009, $19 / 07 / 2009$ and on 22/10/2009.

\section{In situ measurements on the water column}

At each sampling date water column temperature and oxygen concentration were measured by means of a YSI 460 multiple probe, total chlorophyll $a$ concentration was measured by a FluoroProbe II and irradiance in water layers adjacent to sediments was measured with a PAR 193 SA, equipped with CTD probe. Water samples were collected in the deeper portion of the water column, approximately 10 to $20 \mathrm{~cm}$ above the sediment surface, with a Ruttner bottle. They were immediately filtered through $\mathrm{GF} / \mathrm{C}$ filters (pore diameter $0.45 \mu \mathrm{m}$ ) and transferred to plastic (ammonium) or glass (soluble reactive phosphorus) vials. Water samples for soluble reactive phosphorus (SRP) were analyzed within 12 hours while water samples for ammonium $\left(\mathrm{NH}_{4}^{+}\right)$were frozen at $-20^{\circ} \mathrm{C}$ and analyzed within 2 weeks.

\section{Sediment sampling and handling}

During each sampling date, eight intact sediment cores were collected by means of plexiglass liners (i.d. $8 \mathrm{~cm}$, height $30 \mathrm{~cm}$ ) mounted on hand corer. Only cores with visually undisturbed sediments and clear overlaying water were accepted for further treatment. Five cores were incubated in the light and in the dark for flux measurements while three cores were extruded and sliced for pore water analyses of $\mathrm{NH}_{4}{ }^{+}$and SRP. Additionally, $80 \mathrm{~L}$ of in situ water were collected for pre-incubation and incubation procedures.

\section{Intact cores incubation}

In the laboratory, five cores were submerged with the top open into an incubation tank containing in situ aerated 
and well mixed water for overnight preincubation. Rotating teflon-coated magnets were fixed to the inner wall of each core, approx. $6 \mathrm{~cm}$ above the sediment, for gentle water mixing (40 rpm) and avoiding sediment resuspension. Measurements of light and dark flux rates were sequential, with an interval of 2-3 h, and were started the morning after. Incubations in the light were carried out reproducing the irradiance close to the sediment-water interface by means of screened halogen lamps. Before starting the incubation the water level in the tank was lowered just below the core top and water overlying sedi- ments was replaced with filtered fresh in situ water. Incubations were then started by installing floating Plexiglas lids, perfectly fitting the liner inner diameter, on the top of each core. At the beginning of the incubation water samples were collected in triplicate from the tank with 60 $\mathrm{mL}$ plastic syringes. At the end of the incubation the floating lids were removed and water samples were collected from each core. Aliquots of all initial and final water samples were filtered and transferred to glass and plastic vials for nutrient determination. Unfiltered aliquots were transferred to $12 \mathrm{~mL}$ exetainers (Labco, High Wycombe, UK)

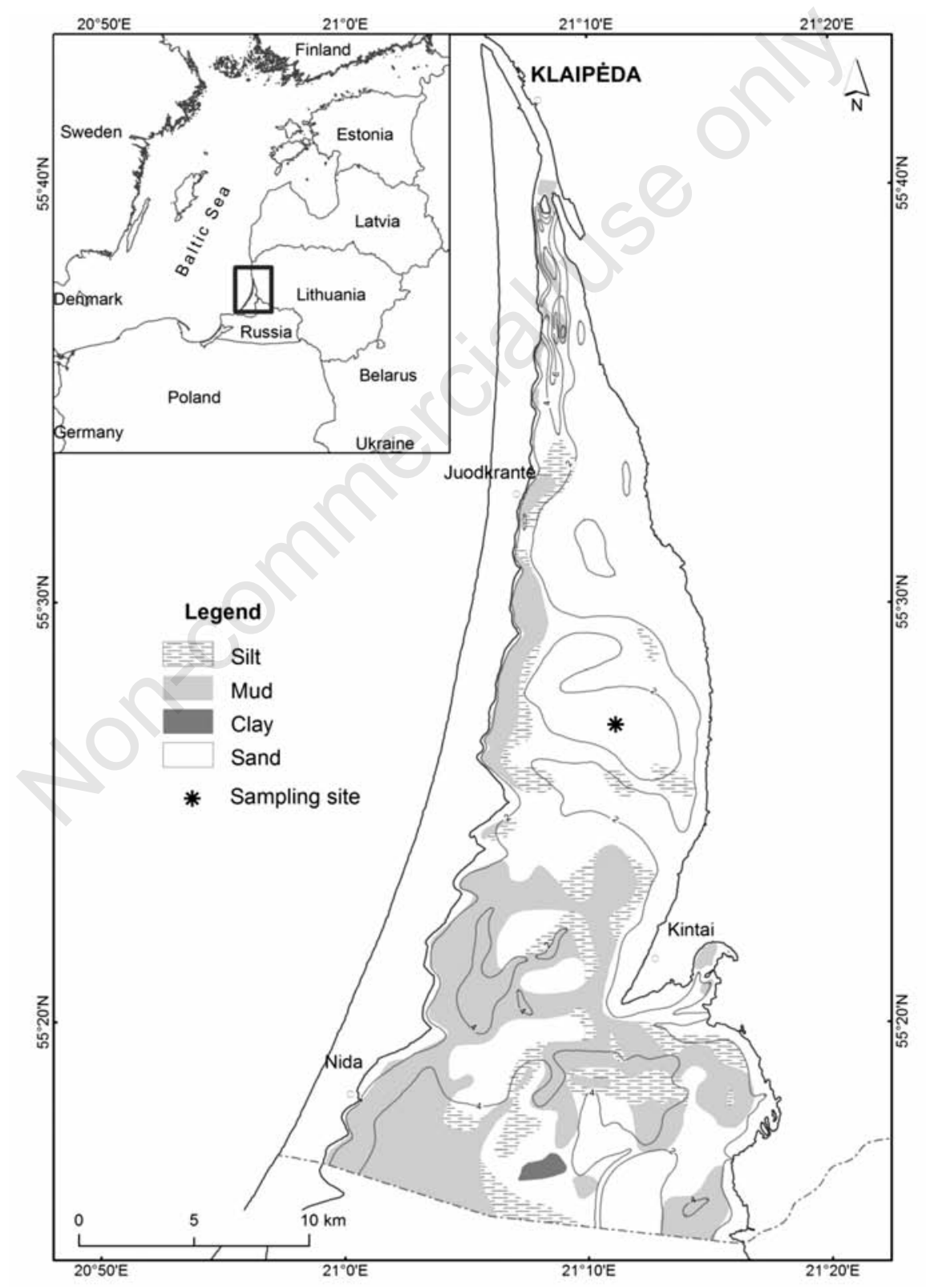

Fig. 1. Map of the Lithuanian part of the Curonian lagoon (southeastern Baltic Sea). The sampling site was located in the central sandy area that is representative of a large fraction of the lagoon bottom. 
and Winkler reagents were immediately added for dissolved oxygen analysis.

Incubation time varied between 3 (May and July) and $5 \mathrm{~h}$ (March and October) and was set in order to keep final oxygen concentration within $20 \%$ of initial values. Fluxes of oxygen, ammonium and reactive phosphorus were calculated according to the following equation (Dalsgaard et al., 2000):

$$
\mathrm{F}=\frac{\left(\mathrm{C}_{\mathrm{f}}-\mathrm{C}_{\mathrm{i}}\right) \times \mathrm{V}}{\mathrm{A} \times \mathrm{t}}
$$

where $\mathrm{F}$ (mmol or $\left.\mu \mathrm{mol} \mathrm{m} \mathrm{m}^{-2} \mathrm{~h}^{-1}\right)$ is the flux; $\mathrm{C}_{\mathrm{i}}$ and $\mathrm{C}_{\mathrm{f}}(\mathrm{mM}$ or $\mu \mathrm{M})$ are the initial and final concentrations, respectively; V (L) is the water volume; $\mathrm{A}\left(\mathrm{m}^{2}\right)$ is the sediment surface and $\mathrm{t}(\mathrm{h})$ is the incubation time.

Oxygen fluxes measured in the light represented net primary production (NPP) by benthic microalgae, while gross primary production (GPP) was calculated as NPP minus community respiration (CR) measured in the dark (Sundbäck et al., 2000). Constant CR under light and dark regime is generally assumed.

Daily nutrient fluxes $\left(\mathrm{mmol} \mathrm{m} \mathrm{m}^{-2} \mathrm{~d}^{-1}\right)$ were calculated according to the following equation:

Daily flux $=\left(\right.$ hourly dark flux $\left.\times \mathrm{h}_{\mathrm{D}}\right)+\left(\right.$ hourly light flux $\left.\times \mathrm{h}_{\mathrm{L}}\right)$

where $h_{D}$ and $h_{L}$ are the average number of dark and light hours in the different sampling periods, respectively. At the end of the incubations sediment porosity $(\varphi)$ was measured in the upper layer $(0-1 \mathrm{~cm}$ depth) by drying 5 $\mathrm{ml}$ of fresh sediment at $60^{\circ} \mathrm{C}$ and calculating the ratio between water to sediment volume. On the same layer the sedimentary content of chlorophyll $a$ was measured spectrophotometrically according to Lorenzen (1967), after extraction in $96 \%$ ethanol of $2.5 \mathrm{~mL}$ of fresh sediment (Jespersen and Christoffersen, 1987).

\section{Pore water extraction and diffusive flux calculation}

Sediments from three cores were extruded, sliced and squeezed for pore water analyses of $\mathrm{NH}_{4}{ }^{+}$and SRP within $8 \mathrm{~h}$ from sampling. Overlying water was removed with a syringe down to the possibly lowest level above the sediment surface. Then sediments were extruded and sliced in a glow bag inflated with $\mathrm{N}_{2}$ in $0.5 \mathrm{~cm}$ thick layers down to $2 \mathrm{~cm}$ sediment depth and then from 2 to 3,3 to 5 and 5 to $10 \mathrm{~cm}$ depth. Pore water was obtained by squeezing fresh sediment under $\mathrm{N}_{2}$ at 1.5-3 bar (KC-Denmark, DK). After $\mathrm{GF} / \mathrm{C}$ filtration pore water was transferred into plastic or glass vials as previously described for spectrophotometric analyses.

Diffusive fluxes of $\mathrm{NH}_{4}^{+}$and SRP at the sedimentwater interface were calculated from nutrient profiles in the sediment by applying the Fick's first law (Berner, 1980):

$$
\mathrm{J}=-\varphi \mathrm{D}_{\mathrm{s}}(\mathrm{dC} / \mathrm{dx})_{\mathrm{x}=0}
$$

where $\mathrm{J}\left(\mathrm{mmol} \mathrm{m} \mathrm{m}^{-2} \mathrm{~d}^{-1}\right)$ is the diffusive flux of one of the target nutrient, $\mathrm{D}_{\mathrm{s}}\left(\mathrm{m}^{2} \mathrm{~d}^{-1}\right)$ is its diffusion coefficient in sediments; $\varphi(0.53)$ is the sediment porosity; $\mathrm{dC} / \mathrm{dx}$ (mmol $\left.\mathrm{m}^{-4}\right)$ is the nutrient concentration gradient across the sediment-water interface. $\mathrm{D}_{\mathrm{S}}$ was determined according to Lerman (1979):

$$
\mathrm{D}_{\mathrm{s}}=\mathrm{D}_{\mathrm{w}}{ }^{0} / \Theta^{2}
$$

where $\mathrm{D}_{\mathrm{w}}{ }^{0}\left(\mathrm{~m}^{-2} \mathrm{~d}^{-1}\right)$ is the diffusion coefficient of $\mathrm{NH}_{4}{ }^{+}$or SRP in the water, taken from Broecker and Peng (1974), while $\Theta^{2}$ is the sediment tortuosity, calculated according to Boudreau (1997):

$$
\Theta^{2}=1-2 \ln \varphi
$$

Diffusion coefficients of nutrients in the water were corrected for the in situ temperature according to the Stokes-Einstein relation (Li and Gregory, 1974). Diffusive fluxes were calculated considering the concentration gradient between the near-bottom and pore water from the uppermost sediment layer. In March the pore water was not analyzed.

\section{Analytical procedures}

Dissolved oxygen was determined via iodometric Winkler titration according to Strickland and Parsons (1972). Ammonium was analyzed spectrophotometrically using the salicylate and hypochlorite method using nitroprusiate as catalyst (Bower and Holm-Hansen, 1980). Soluble reactive phosphorus was analyzed by a flow injection analyzer (FIAstar ${ }^{\mathrm{TM}}$ 5000, Foss, Denmark) by using molybdate blue method (Grasshoff et al., 1983).

\section{Data analysis}

The analysis of variance (two-way ANOVA) was used to test whether differences between seasonal measurements and between fluxes in the light and in the dark were statistically significant. Homogeneity of variance was checked using Cochran's test, data transformation was applied if significant heteroscedascity was found. When significant interaction between factors was found, a pair-wise comparison of means was carried with Tukey post-hoc test. Differences between means were considered statistically significant if the $\mathrm{P}$ value was less than 0.05 .

\section{RESULTS}

\section{Water column and surface sediment features}

Among the studied water physico-chemical parameters some did not show any significant seasonal variation 
(i.e. salinity, that was always $<1 \%$, dissolved oxygen, that was always below $100 \%$, and SRP, always $<1 \mu \mathrm{M}$ ), while others displayed large fluctuations (i.e. temperature and chlorophyll a) (Tab. 1). The summer peak of chlorophyll $a$ coincided with the bloom phase of cyanobacteria and was coupled to that found in surface sediments (Tab. 2). Photosynthetically active radiation (PAR) in the bottom water layer adjacent to the sediment, showed pronounced variations in the transition between spring and summer blooms, with higher light availability at the sedimentwater interface in the post bloom period.

\section{Nutrient profiles and diffusive fluxes}

Ammonium concentrations in the surface sediment were typically higher than those measured in the overlaying water (Fig. 2). The average $\mathrm{NH}_{4}^{+}$concentration along the $0-10 \mathrm{~cm}$ sediment profile was relatively constant

Tab. 1. Physico-chemical features of bottom water at the study site during the four sampling dates. Nutrient data is reported as average \pm standard deviation $(n=3)$.

\begin{tabular}{lccc}
\hline Sampling date & $16 / 03 / 2009$ & $20 / 05 / 2009$ & $19 / 07 / 2009$ \\
\hline Temperature $\left({ }^{\circ} \mathrm{C}\right)$ & 2 & 17 & $22 / 10 / 2009$ \\
Salinity $(\% 0)$ & 0.19 & 0.25 & 9 \\
$\mathrm{Chl} a\left(\mu \mathrm{g} \mathrm{L}^{-1}\right)$ & 19 & 18 & 0.20 \\
$\mathrm{O}_{2}(\%)$ & 67 & 81 & 56 \\
$\mathrm{NH}_{4}^{+}(\mu \mathrm{M})$ & $3.1 \pm 0.8$ & $4.8 \pm 1.3$ & 85 \\
$\mathrm{SRP}(\mu \mathrm{M})$ & $0.5 \pm 0.1$ & $0.5 \pm 0.1$ & $30.4 \pm 9.4$ \\
\hline
\end{tabular}

Tab. 2. Sedimentary features measured or calculated at the four sampling dates at the study site. Irradiance, measured in the proximity of the sediment surface, represents the light available to benthic microalgae in the different periods. Chl $a$ (average \pm standard deviation, $\mathrm{n}=3$ ) was measured in the $0-1 \mathrm{~cm}$ upper sediment layer and is a proxy of benthic microalgal biomass. Diffusive nutrient fluxes (average \pm standard deviation, $\mathrm{n}=3$ ) were calculated from gradients between bottom and pore water (see the text for more details). Positive fluxes are from the sediment to the water column while negative fluxes are from the water to the sediment.

\begin{tabular}{|c|c|c|c|c|}
\hline Sampling date & $16 / 03 / 2009$ & $20 / 05 / 2009$ & $19 / 07 / 2009$ & $22 / 10 / 2009$ \\
\hline Irradiance $\left(\mu \mathrm{E} \mathrm{m}^{-2} \mathrm{~s}^{-1}\right)$ & 90 & 130 & 30 & 70 \\
\hline Chl $a\left(\mathrm{mg} \mathrm{m}^{-2}\right)$ & $74 \pm 12$ & $60 \pm 8$ & $131 \pm 17$ & $79 \pm 13$ \\
\hline \multicolumn{5}{|c|}{ Diffusive fluxes $\left(\mathrm{mmol} \mathrm{m} \mathrm{m}^{-2} \mathrm{~d}^{-1}\right)$} \\
\hline $\mathrm{NH}_{4}^{+}$ & n.d. & $0.21 \pm 0.12$ & $2.95 \pm 1.75$ & $0.55 \pm 0.17$ \\
\hline SRP & n.d. & $0.02 \pm 0.00$ & $0.05 \pm 0.01$ & $<0.001$ \\
\hline
\end{tabular}

Tab. 3. Results of two-way ANOVA applied to oxygen $\left(\mathrm{O}_{2}\right)$, ammonium $\left(\mathrm{NH}_{4}^{+}\right)$and soluble reactive phosphorus (SRP) flux data obtained via intact cores incubation. The tested factors were sampling seasons and incubation condition (light or dark regime). $\log \left(\mathrm{x}^{2}\right) \operatorname{transfor-}$ mation was applied to $\mathrm{NH}_{4}{ }^{+}$flux data when significant heteroscedascity was found.

\begin{tabular}{|c|c|c|c|c|c|}
\hline Factor & Df & SS & MS & $\mathrm{F}$ & $\mathrm{P}$ \\
\hline \multicolumn{6}{|l|}{$\overline{O_{2} f l u x}$} \\
\hline Season & 3 & 15.4 & 5.1 & 55.2 & $<0.001$ \\
\hline Light-dark & 1 & 21.0 & 21.0 & 224.9 & $<0.001$ \\
\hline Season $\times$ light-dark & 3 & 1.3 & 0.4 & 4.6 & $<0.01$ \\
\hline Residual & 32 & 3.0 & 0.1 & & \\
\hline Total & 39 & 40.6 & 1.0 & & \\
\hline \multicolumn{6}{|l|}{$\mathrm{NH}_{4}^{+}$flux } \\
\hline Season & 3 & 20.9 & 7.0 & 19.4 & $<0.001$ \\
\hline Light-dark & 1 & 9.7 & 9.7 & 27.1 & $<0.001$ \\
\hline Season×light-dark & 3 & 1.6 & 0.5 & 1.5 & 0.235 \\
\hline Residual & 32 & 11.5 & 0.4 & & \\
\hline Total & 39 & 43.7 & 1.1 & & \\
\hline \multicolumn{6}{|l|}{ SRP flux } \\
\hline Season & 3 & 18.1 & 6.0 & 4.6 & $<0.01$ \\
\hline Light-dark & 1 & 2.1 & 2.1 & 1.6 & 0.215 \\
\hline Season $\times$ light-dark & 3 & 27.7 & 9.2 & 7.0 & $<0.001$ \\
\hline Residual & 32 & 42.4 & 1.3 & & \\
\hline Total & 39 & 90.3 & 2.3 & & \\
\hline
\end{tabular}

Df, degree of freedom; SS, sum of squares; MS, means of squares; F, F-statistics; P, P-value. 
(63.8 $\pm 17.3 \mu \mathrm{M}$, pooled data) in spring and autumn, however it was much higher (up to $625.0 \mu \mathrm{M}$ ) during summer, in particular in the upper $2 \mathrm{~cm}$ layer. $\mathrm{As}_{\mathrm{NH}_{4}}^{+}$in bottom water was relatively constant in the sampling periods, calculated diffusive ammonium transport reflected the seasonal evolution of pore water, with the highest efflux calculated in July (Tab. 2).

Pore water SRP concentration was relatively low and homogeneous along the sediment vertical profile in May, and increased significantly in summer and autumn, in particular in subsurface layers (Fig. 2). In July, similarly to what evidenced for ammonium, pore water SRP accumulated in the upper sediment horizon with a concentration peak of $26.4 \mu \mathrm{M}$ at $1.5 \mathrm{~cm}$ depth. The concentration gradient across the sediment-water interface and the calculated diffusive fluxes were maximum in the summer; while in October SRP gradients and fluxes at the interface were negligible (Tab. 2).

\section{Light and dark intact core incubations}

Oxygen fluxes at the sediment-water interface were significantly affected by the light regime and the sampling season (Fig. 3, Tab. 3). In spring and in autumn, in the light incubation, sediments were net autotrophic (NPP $>0)$, while in summer they were net heterotrophic (NPP= $\left.-0.9 \pm 0.3 \mathrm{mmol} \mathrm{m}^{-2} \mathrm{~h}^{-1}\right)$. NPP were negatively related to the sediment chlorophyll $a(\mathrm{r}=-0.97, \mathrm{P}<0.05)$. Gross primary production (GPP) of benthic microalgae ranged between 0.3 and $2.8 \mathrm{mmol} \mathrm{m}^{-2} \mathrm{~h}^{-1}$, with the lowest average value measured in July $\left(1.0 \pm 0.4 \mathrm{mmol} \mathrm{m}^{-2} \mathrm{~h}^{-1}\right)$. In contrast, community respiration (CR) followed the seasonal temperature pattern with significantly higher rates measured in July $\left(-1.9 \pm 0.4 \mathrm{mmol} \mathrm{m}^{-2} \mathrm{~h}^{-1}\right)$, coinciding with the highest water temperature (Tukey HSD test, $\mathrm{P}<0.05$ ).

Nutrient fluxes differed significantly between seasons, while the effects of light-dark regime and its interaction with the sampling season were different for the two nutrients. The factor light affected significantly only ammonium fluxes (Tukey HSD test, $\mathrm{P}<0.05$ ) in all sampling periods. In the light ammonium was consistently taken up by sediments (average of pooled data $28.1 \pm 20.2 \mu \mathrm{mol} \mathrm{m}^{-2} \mathrm{~h}^{-1}$ ), with significantly lower rates measured in March (Tukey HSD test, $\mathrm{P}<0.05)$. In the dark ammonium release to the near bottom water exhibited seasonal variations (Fig. 3), with increasing efflux rates from March to October (22.0 \pm 13.5 and $189.5 \pm 76.0 \mu \mathrm{mol} \mathrm{m} \mathrm{m}^{-2} \mathrm{~h}^{-1}$, respectively).

In contrast to what observed for $\mathrm{NH}_{4}^{+}$, surface sediments always acted as a sink for SRP in both light and dark conditions $\left(1.4 \pm 1.5 \mu \mathrm{mol} \mathrm{m} \mathrm{m}^{-2} \mathrm{~h}^{-1}\right.$, average of pooled data). SRP uptake increased from March to July and there-

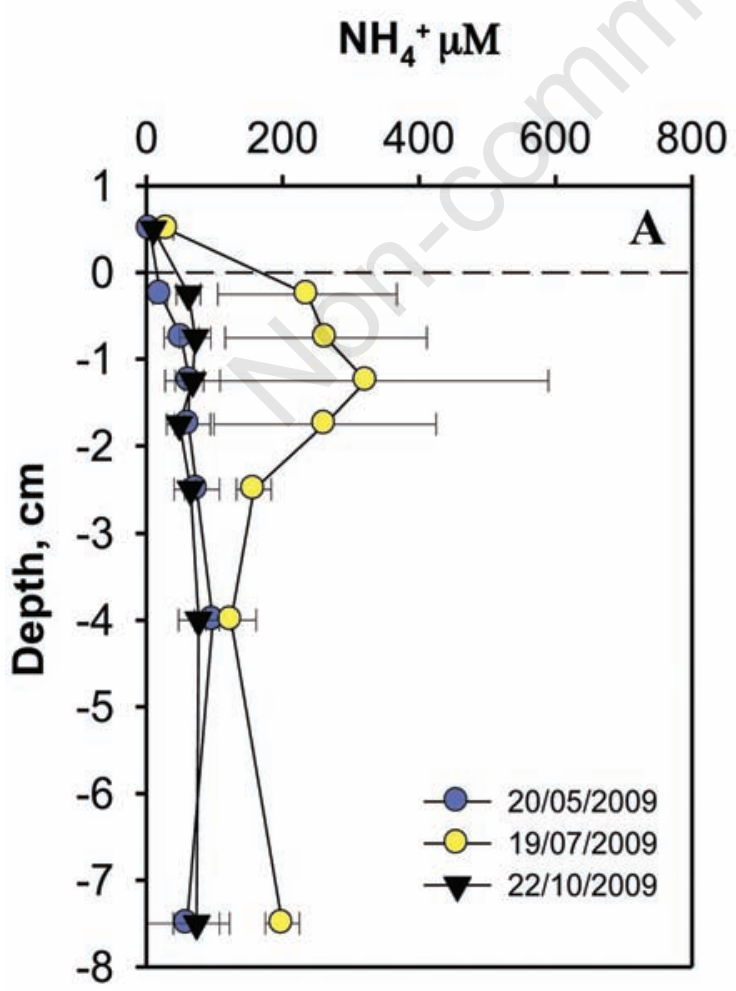

SRP $\mu \mathrm{M}$

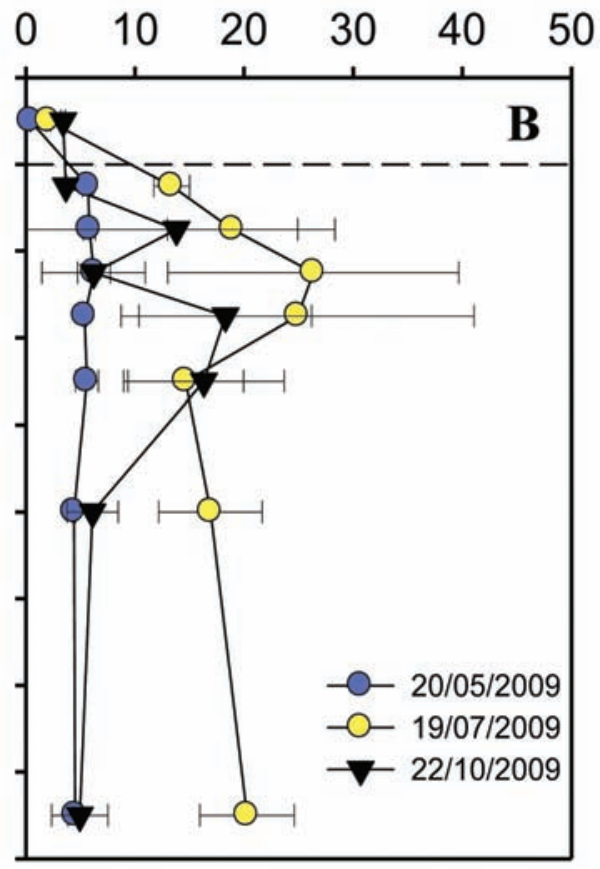

Fig. 2. Concentrations of ammonium (A) and soluble reactive phosphorus (B) in the pore water in May, July and October 2009 at the sampling site of Curonian lagoon. Points and triangles, averages; bars, standard deviations $(\mathrm{n}=3)$. 
after decreased in October. Differences between light and dark incubations did not follow a clear pattern (Fig. 3 and Tab. 3) and were significantly different only in July (Tukey HSD test, $\mathrm{P}<0.05$ ).

\section{DISCUSSION}

The current study is not conclusive but stands for an initial, ex situ attempt to evaluate whether benthic microalgae affect surface sediment dynamics in a turbid ecosystem. Such issue has been and still is poorly explored in very productive environments as the Curonian lagoon, as demonstrated by the scarce specific literature. In this respect, the novelty represented by our research is that it provides multiple evidences of photosynthetic activity at the sediment-water interface, as the significant differences between light and dark solute fluxes and the discrepancies between expected diffusive and measured rates.

Our approach has some limits: in shallow water systems as the Curonian lagoon, calculated diffusive exchanges generally allow to evaluate only the direction and the potential magnitude of a flux. This is a consequence of the rough vertical resolution that can be obtained extruding and slicing cores (generally not below $5 \mathrm{~mm}$ ), which is sometimes insufficient to appreciate the very steep vertical gradients in organic enriched sediments with elevated microbial activity. In fact, the introduction in the 80 's of microelectrodes in microbial ecology studies has clarified how complex are oxygen and nitrogen dynamics on millimetric or sometimes submillimetric scales with very thin oxic horizons and very spatially confined and coupled processes (Revsbech et al., 1980; Meyer et al., 2001; Rysgaard et al., 2004).

We acknowledge that the adopted vertical resolution can lead to overestimated efflux of ammonium; in the upper oxic layer in fact, processes like nitrification can considerably lower the pore water concentrations of this nutrient, and consequently reduce the chemical gradients with bottom water. On the other hand, in this lagoon oxygen penetration is seldom thicker than $1 \mathrm{~mm}$ (Zilius et al., 2012), and denitrification measurements with the IPT techniques demonstrated that nitrification, as a $\mathrm{NH}_{4}^{+}$consuming process, is very low in this lagoon (Zilius, 2011). To our knowledge there are no published informations on SRP microprofiles and we thus cannot discuss whether the resolution of our profiles leads to wrong estimates of true phosphorous fluxes. Furthermore, bioturbation activities by large macrofauna, not considered in the present study, can strongly enhance, up to a factor 4 , the regeneration of nutrients (Glud et al., 2003; Stief and De Beer, 2006; Bartoli et al., 2009). As a consequence, theoretical, diffusive fluxes calculated in bioturbated sediments can largely underestimate fluxes measured with intact cores incubation. We know from previous studies that in the
Curonian lagoon the presence of macrofauna is occasional (Daunys, 2001) and in the cores collected for the present study there were no signs of the presence of large macrofauna, with a thin layer of light brown sediment overlying a thick dark layer. We can thus exclude a significant contribution of macrofauna in measured rates.
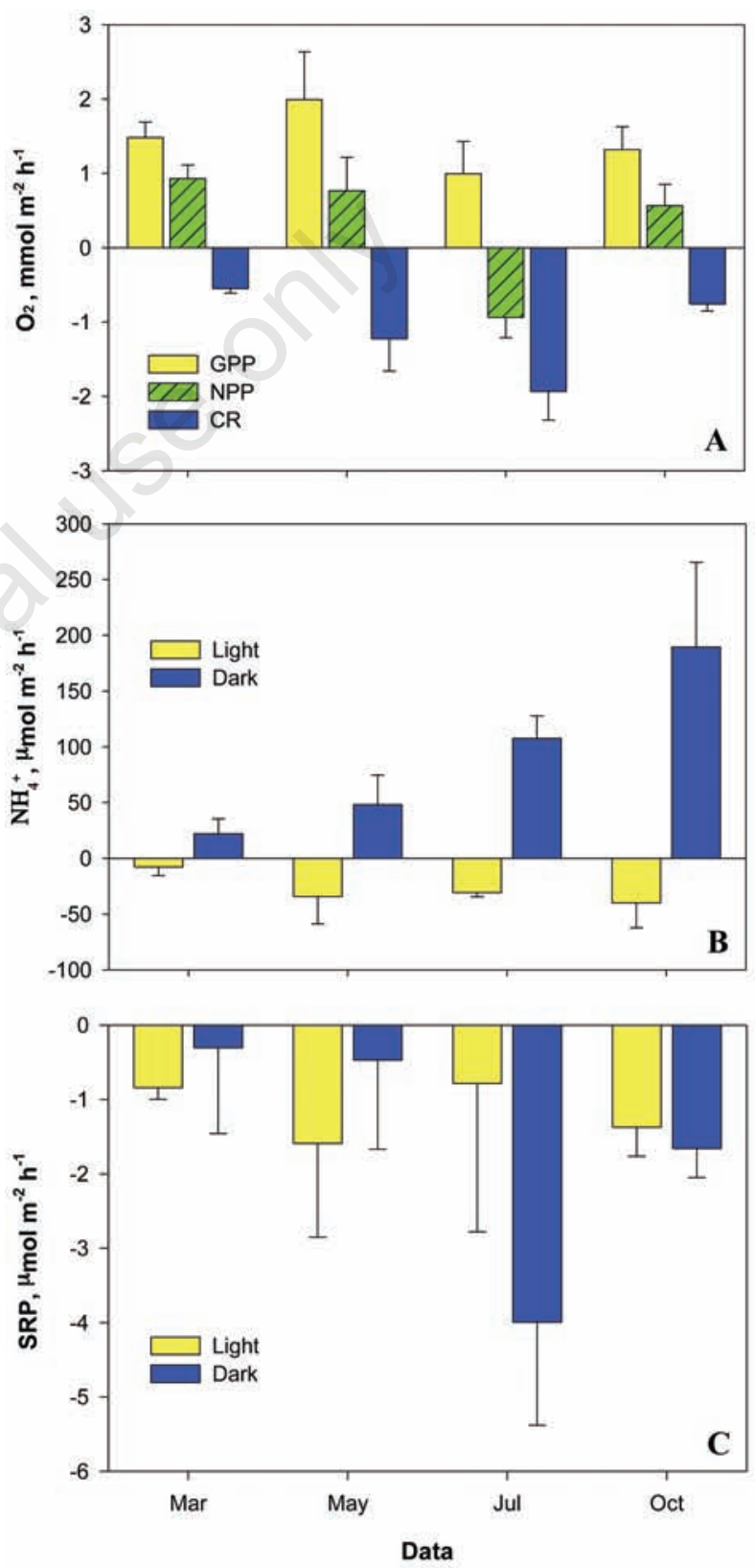

Fig. 3. A) Rates of net and gross primary production (NPP and GPP) and of community respiration (CR), B) ammonium and C) soluble reactive phosphorus total fluxes. Measurements were realized via intact cores incubations in the light and in the dark in 4 periods (March, May, July and October in 2009). Average \pm standard deviations are reported $(n=5)$. 
Another factor affecting fluxes at the sediment-water interface is the presence of an active layer of benthic microalgae (Sundbäck et al., 2000 and references therein). In highly productive and shallow coastal areas the activity of benthic microalgae is generally controlled by turbidity and light penetration (Sundbäck et al., 2004; Gerbersdorf et al., 2005; Köster et al., 2005). In the hypertrophic Curonian lagoon elevated turbidity is determined by high densities of pelagic microalgae, which attenuate the light reaching the surface sediment, with irradiance values frequently below $20 \mu \mathrm{E} \mathrm{m}^{-2} \mathrm{~s}^{-1}$ (Zilius et al., unpublished). Under such conditions benthic photosynthesis is strongly limited; however phytoplankton turnover and frequent primary production crashes in this system do allow for transient periods where light availability is higher and where irradiance at the sediment surface is more favorable for benthic microalgae. Glud et al. (2002) found that in arctic sediments settled diatoms can efficiently optimize their physiologically activity under existing light conditions. It is also known that under unfavorable light regimes benthic microalgae can stay viable, although their metabolism (including uptake of pore water nutrients) is maintained at low levels (Sundbäck et al., 2004).

We believe that significant differences in both oxygen
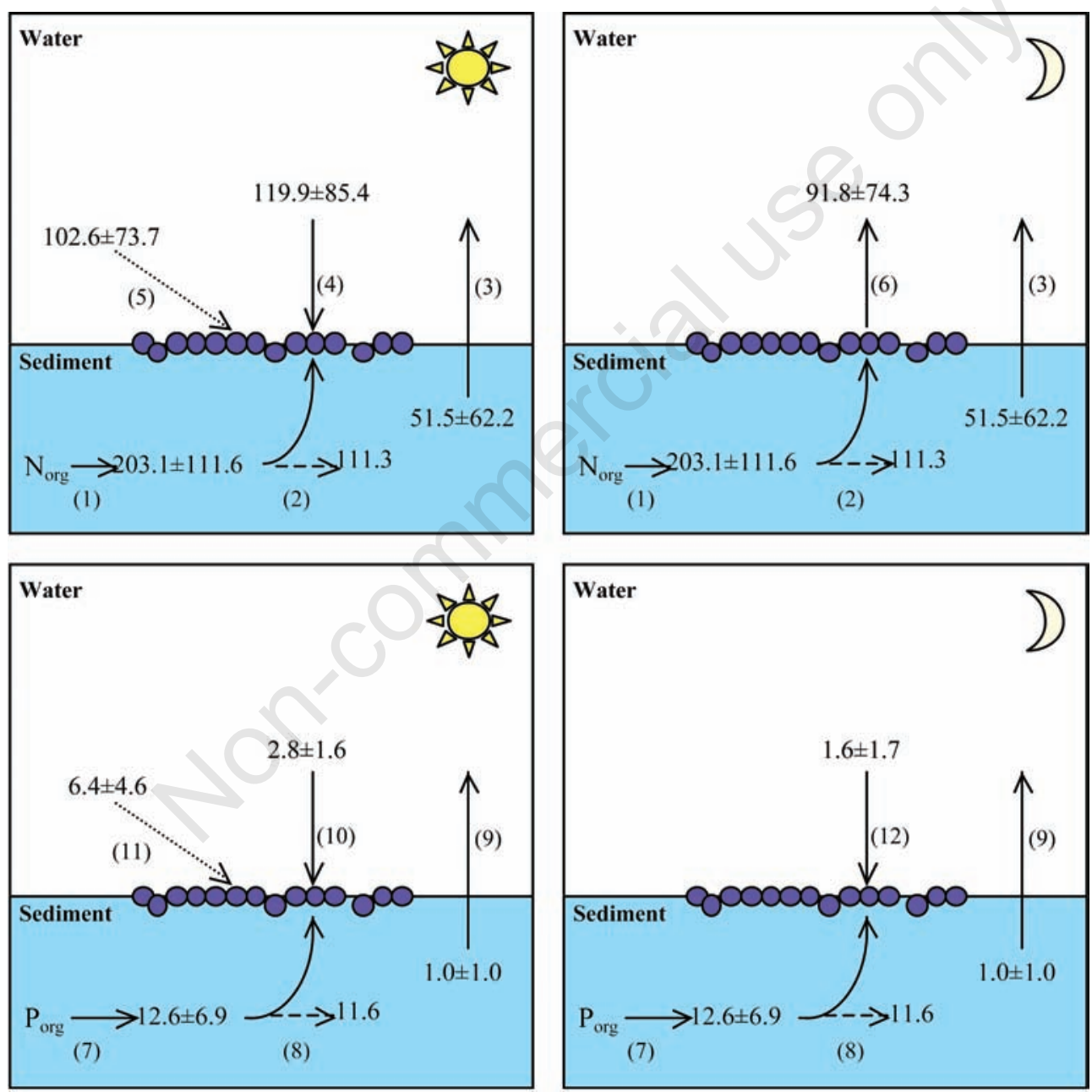

Fig. 4. Net measured and theoretical ammonium $\left(\mathrm{NH}_{4}^{+}\right)$and soluble reactive phosphorus (SRP) fluxes in the light and in the dark ( $\mu$ mol $\mathrm{m}^{-2} \mathrm{~h}^{-1}$, pooled data). (1) Rates of ammonification, calculated from dark oxygen respiration and C:N ratio of surface sediment; (2) $\mathrm{NH}_{4}^{+}$ consuming processes, e.g. nitrification, adsorption or bacterial assimilation; (3) theoretical diffusive $\mathrm{NH}_{4}^{+}$efflux obtained from concentration gradients; (4) measured net $\mathrm{NH}_{4}^{+}$uptake (from intact core incubation); (5) theoretical net $\mathrm{NH}_{4}^{+}$uptake, calculated from net primary production (assuming $\mathrm{C}: \mathrm{N}=6.6$ and photosynthetic quotient=1.2); (6) net $\mathrm{NH}_{4}{ }^{+}$efflux in the dark (from intact core incubation); (7) SRP regeneration, calculated from dark oxygen consumption and C:P ratio of surface sediment; (8) SRP consuming processes (precipitation, adsorption, bacterial uptake); (9) theoretical diffusive SRP efflux obtained from concentration gradients; (10) measured net SRP uptake (from intact core incubation); (11) theoretical net SRP uptake, calculated from net primary production (assuming C:P=106 and photosynthetic quotient=1.2); (12) net dark SRP flux at the sediment-water interface (from intact core incubation). 
and ammonium fluxes between dark and light incubations, observed in all sampling periods, can be reasonably addressed to the activity of benthic microalgae. Benthic microalgae are responsible for significant fractions of benthic oxygen production and nitrogen retention due their photosynthetic and assimilation activities (Christensen et al., 1990; Lorenzen et al., 1998; Sundbäck et al., 2000; Meyer et al., 2001; Köster et al., 2005). Simultaneously, the activity of benthic microalgae can expand the oxic zone and may stimulate ammonium oxidation throughout nitrification (Risgaard-Petersen et al., 1994; Lorenzen et al., 1998; Meyer et al., 2001). The combination of benthic microalgae direct (uptake) and indirect (nitrification) effects can significantly attenuate ammonium regeneration or reverse its flux during the light period, as suggested by our results. Differences between light and dark fluxes of soluble reactive phosphorous were not significant meaning a less evident direct role of benthic microalgae in regulating the benthic fluxes of this ion. Negative fluxes of soluble reactive phosphorous measured at all sampling periods can be an indirect consequence of benthic microalgae activity at the interface: the oxygenation of the upper sediment layer in fact allow the regeneration of sedimentary buffers (i.e. $\mathrm{Fe}^{3+}$, that co-precipitates $\mathrm{PO}_{4}{ }^{3-}$ in insoluble forms) (Sundbäck and Graneli, 1988).

Assuming similar rates of organic carbon, nitrogen and phosphorus oxidation for the labile algal cells pool that constitutes a major fraction of the organic matter in the surficial Curonian lagoon sediments, dark rates of oxygen uptake can be converted into rates of $\mathrm{CO}_{2}, \mathrm{NH}_{4}^{+}$ and $\mathrm{PO}_{4}{ }^{3-}$ mineralization. To this purpose, we assumed a 1.2 molar ratio between $\mathrm{CO}_{2}$ and $\mathrm{O}_{2}$ as the respiratory quotient in the more reactive upper oxic layer and $\mathrm{C}: \mathrm{N}$ and C:P molar ratios of 6.6 and 106, respectively (Redfield, 1958). Analogously, net oxygen fluxes in the light can be converted into rates of $\mathrm{N}$ and $\mathrm{P}$ uptake by the benthic microalgal community (Sundbäck et al., 2000 and references therein). We acknowledge that there is a large variability between reported respiratory and photosynthetic quotients and nutrient ratios in surface sediments; however our intent here is not to provide a detailed estimation of benthic nutrient mineralization or uptake but rather to speculate whether benthic microalgal activity can explain the differences between light and dark nutrient fluxes and between core incubation and diffusive flux estimates. A synthetic representation of these calculations is provided in Fig. 4, where we have averaged rates and fluxes measured, modelled or estimated in the different sampling periods. Average annual net ammonium production within sediments, which is a proxy for ammonification rates, sustains a gradient from the sediment to the water, as predicted by the application of Fick's law (Fig. 4). Net ammonium fluxes in the light are anyway negative and opposite to such gradient, suggesting the presence of a large $\mathrm{N}$ sink at the interface. Theoretical $\mathrm{N}$ requirements, calculated from oxygen fluxes (NPP), are smaller that ammonium influx, likely due to underestimated oxygen production (and ammonium uptake). In fact, a large fraction of oxygen produced at the interface is probably driven downwards or consumed by the benthic community respiration. In the dark, attenuated uptake by benthic microalgae reverse the situation and net ammonium efflux is measured, as expected by large ammonification and by physical gradients of pore water.

Results from $P$ benthic dynamics are similar but highlight a probable different regulation of $\mathrm{P}$ mobility at the interface, regulated not only by uptake but also by geochemical reactions (i.e. co-precipitation with oxidized metal forms). In fact, in both light and dark conditions net measured fluxes are contrasting the (small) upwards gradient, suggesting again the presence of a surficial sink (the microalgae uptake) but also probably of other reactive $\mathrm{P}$ trapping compounds $\left(\right.$ i.e. $\mathrm{Fe}^{3+}$ ). Theoretical $\mathrm{P}$ uptake, likely underestimated by $50 \%$, as for $\mathrm{N}$, represents in fact a small fraction of mineralized SRP, which is retained within sediment and not released in the dark (Fig. 4).

\section{AKNOWLEDGMENTS}

The authors gratefully thank students Kasparas Bagdonas and Rūta Žilienė for their enthusiastic help during field sampling and laboratory experiments.

This study was financially supported by BONUS ERA-NET PLUS project AMBER.

\section{REFERENCES}

Bartoli M, Nizzoli D, Viaroli P, 2003. Microphytobenthos activity and fluxes at the sediment-water interface: interactions and spatial variability. Aquat. Ecol. 37: 341-349.

Bartoli M, Vezzulli L, Nizzoli D, Azzoni R, Porrello P, Moreno M, Fabiano F, Viaroli P, 2009. Short-term effect of oxic to anoxic transition on benthic microbial activity and solute fluxes in organic-rich phytotreatment ponds. Hydrobiologia 629:123-136.

Berner RA, 1980. Early diagenesis: a theoretical approach. Princeton University Press, Princeton.

Boudreau BP, 1997. Diagenetic models and their implication: modeling transport and reactions in aquatic sediments. Springer, Berlin.

Bower CE, Holm-Hansen T, 1980. A salicylate-hypochlorite method for determining ammonia in seawater. Can. J. Fish. Aquat. Sci. 37: 794-798.

Broecker WS, Peng TH, 1974. Gas exchange rates between air and sea. Tellus 26: 21-35.

Callender E, Hammond DE, 1982. Nutrient exchange across the sediment-water interface in the Potomac River estuary. Estuar. Coast. Shelf S. 15: 395-413.

Christensen PB, Nielsen LP, Sørensen J, Revsbech NP, 1990. Denitrification in nitrate-rich streams: diurnal and seasonal variation related to benthic oxygen metabolism. Limnol. Oceanogr. 35: 640-651. 
Conley DJ, Malone TC, 1992. Annual cycle of dissolved silicate in Chesapeake Bay: implications for the production and fate of phytoplankton biomass. Mar. Ecol.-Prog. Ser. 81: 121128.

Conley DJ, Pearl HW, Howarth RW, Boesch DF, Seitzinger SP, Havens KE, Lancelot C, Likens GE, 2009. Controlling eutrophication: nitrogen and phosphorus. Science 323: 10141015.

Cowan JLW, Boynton WR, 1996. Sediment-water oxygen and nutrient exchanges along the longitudinal axis of Chesapeake Bay: seasonal patterns, controlling factors and ecological significance. Estuaries 19: 562-580.

Dailidienè I, Davulienė L, 2007. Long-term mean salinity in the Curonian Lagoon in 1993-2005. Acta Zool. Lituanica 17: 172-181.

Dailidiene I, Davulienè L, 2008. Salinity trend and variation in the Baltic Sea near the Lithuanian coast in the Curonian Lagoon in 1984-2005. J. Marine Syst. 74: 520-529.

Dalsgaard T, Nielsen LP, Brotas V, Viaroli P, Underwood G, Nedwell D, Sundbäck K, Rysgaard S, Miles A, Bartoli M, Dong L, Thornton DCO, Otossen LDM, Castaldelli G, Risgaard-Petersen N, 2000. Protocol handbook for NICE - Nitrogen Cycling In Estuaries. A project under the EU research programme: Marine Science and Technology (MAST III). National Environmental Research Institute, Silkeborg, p. 43.

Daunys D, 2001. Patterns of the bottom macrofauna variability and its role in the shallow coastal Lagoon. Summary of PhD Thesis, Klaipeda University, Klaipeda.

Ferrarin C, Razinkovas A, Gulbinskas S, Umgiesser G, Bliūdžiute L, 2008. Hydraulic regime-based zonation scheme of the Curonian Lagoon. Hydrobiologia 611:133-146.

Gasiūnaite ZR, 2000. Coupling of the limnetic and brackishwater plankton crustaceans in the Curonian lagoon (Baltic Sea). Int. Rev. Hydrobiol. 85: 653-662.

Gerbersdorf SU, Meyercordt J, Meyer-Reil LA, 2005. Microphytobenthic primary production in the Bodden estuaries, southern Baltic Sea, at two study sites differing in trophic status. Aquat. Microb. Ecol. 41: 181-198.

Glud RN, Kuhl M, Wenzhöfer F, Rysgaard S, 2002. Benthic diatoms of a high Arctic fjord (Young Sound, NE Greenland): importance for ecosystem primary production. Mar. Ecol.Prog. Ser. 238: 15-29.

Glud RN, Gundersen JK, Røy H, Jørgensen BB, 2003. Seasonal dynamics of benthic $\mathrm{O}_{2}$ uptake in a semi-enclosed bay: importance of diffusion and fauna activity. Limnol. Oceanogr. 48: 1265-1276.

Grasshoff K, Ehrhardt M, Kremling K, 1983. Methods of seawater analysis, $2^{\text {nd }} e d$. Verlag Chemie, Berlin.

Grossart HP, Simon M, Logan BE, 1997. Formation of macroscopic organic aggregates (lake snow) in a large lake: the significance of transparent exopoly-saccharide particles (TEP), phyto-, and zooplankton. Limnol. Oceanogr. 42: 1651-1659.

Howarth RW, 1988. Nutrient limitation of net primary production in marine systems. Annu. Rev. Ecol. Syst. 19: 89-110.

Jensen HS, Mortensen PB, Andersen F $\varnothing$, Rasmussen E, Jensen A, 1995. Phosphorus cycling in a coastal marine sediment, Aarhus Bay, Denmark. Limnol. Oceanogr. 40: 908-917.

Jensen MH, Lomstein E, Sørensen L, 1990. Benthic $\mathrm{NH}_{4}{ }^{+}$and $\mathrm{NO}_{3}{ }^{-}$flux following sedimentation of a spring phytoplankton bloom in Aarhus Bight, Denmark. Mar. Ecol.-Prog. Ser. 61: 87-96.

Jespersen AM, Christoffersen K, 1987. Measurements of chlorophyll a from phytoplankton using ethanol as extraction solvent. Arch. Hydrobiol. 109: 445-454.

Jokšas K, Galkus A, Stakènienė R, 1998. Geocheminiai Kuršių marių dugno nuosėdų ypatumai ir juos formuojantys veiksniai. [Article in Lithuanian]. Geographical Yearbook 31: 123-144.

Köster M, Dahlke S, Meyer-Reil LA, 2005. Microbial colonization and activity in relation to organic carbon in sediments of hypertrophic coastal waters (Nordrügensche Bodden, Southern Baltic Sea). Aquat. Microb. Ecol. 39: 69-83.

Kristensen E, 2000. Organic matter diagenesis at the oxic/anoxic interface in coastalmarine sediments, with emphasis on the role of burrowing animals. Hydrobiologia 426: 1-24.

Larson F, Sundbäck K, 2008. Role of microphytobenthos in recovery of functions in a shallow-water sediment system after hypoxic events. Mar. Ecol.-Prog. Ser. 357: 1-16.

Li YH, Gregory S, 1974. Diffusion of ions in sea water and in deep-sea sediments. Geochim. Cosmochim. Ac. 38: 703714.

Lerman A, 1979. Geochemical processes: water and sediment environments. John Wiley \& Sons, New York.

Lorenzen CJ, 1967. Determination of chlorophyll and pheo-pigments: spectrophotometric equations. Limnol. Oceanogr. 12: 343-346.

Lorenzen J, Larsen LH, Kjaer T, Revsbech NP, 1998. Biosensor determination of the microscale distribution of nitrate, nitrate assimilation, nitrification, and denitrification in a diatom-inhabited freshwater sediment. Appl. Environ. Microbiol. 64: 3264-3269.

Meyer RL, Kjær T, Revsbech NP, 2001. Use of $\mathrm{NO}_{\mathrm{x}}{ }^{-}$microsensors to estimate the activity of sediment nitrification and $\mathrm{NO}_{\mathrm{x}}{ }^{-}$consumption along an estuarine salinity, nitrate, and light gradient. Aquat. Microb. Ecol. 26: 181-193.

Ogilvie B, Nedwell DB, Harrison RM, Robinson A, Sage A, 1997. High nitrate, muddy estuaries as nitrogen sinks: the nitrogen budget of the River Colne estuary (United Kingdom). Mar. Ecol.-Prog. Ser. 150: 217-228.

Pelegrí SP, Blackburn TH, 1995. Effect of bioturbation by Nereis sp., Mya arenaria and Cerastoderma sp. on nitrification and denitrification in estuarine sediments. Ophelia 42: 289-299.

Pilkaityte R, Razinkovas A, 2006. Factors controlling phytoplankton blooms in a temperate estuary: nutrient limitation and physical forcing. Hydrobiologia 555: 41-48.

Pilkaityte R, Razinkovas A, 2007. Seasonal changes in phytoplankton composition and nutrient limitation in a shallow Baltic lagoon. Boreal Environ. Res. 12: 551-559.

Pustelnikovas O, 1998. Geochemistry of Sediments of the Curonian Lagoon (Baltic Sea). Institute of Geography, Vilnius.

Razinkovas A, Pilkaityte R, 2002. Factors limiting phytoplankton development in the Curonian lagoon. [Article in Lithuanian]. Jūra ir aplinka 1: 39-46.

Redfield A, 1958. The biological control of chemical factors in the environment. Am. Sci. 46: 205-221.

Revsbech NP, Sørensen J, Blackburn TH, Lomholt LP, 1980. Distribution of oxygen in marine sediments measured with microelectrodes. Limnol. Oceanogr. 25: 403-411. 
Risgaard-Petersen N, Rysgaard S, Nielsen LP, Revsbech NP, 1994. Diurnal variation of denitrification and nitrification in sediment by colonized benthic microphytes. Limnol. Oceanogr. 39: 573-579.

Rysgaard S, Glud RN, Risgaard-Petersen N, Dalsgaard T, 2004. Denitrification and anammox activity in Arctic marine sediments. Limnol. Oceanogr. 49: 1493-1502.

Seitzinger SP, 1988. Denitrification in freshwater and coastal marine ecosystems: ecological and geochemical significance. Limnol. Oceanogr. 33: 702-724.

Stief P, De Beer D, 2006. Probing the microenvironment of freshwater sediment macrofauna: Implications of depositfeeding and bioirrigation for nitrogen cycling. Limnol. Oceanogr. 51: 2538-2548.

Strickland JDH, Parsons TR, 1972. A practical handbook of seawater analysis, $2^{\text {nd }}$ ed. B. Fish. Res. Board Can. 167: 311 p.

Sundbäck K, Graneli W, 1988. Influence of microphytobenthos on the nutrient flux between sediment and water: a laboratory study. Mar. Ecol.-Prog. Ser. 43: 63-69.

Sundbäck K, Linares F, Larson F, Wulff A, 2004, Benthic nitrogen fluxes along a depth gradient in a microtidal fjord: The role of denitrification and microphytobenthos. Limnol.
Oceanogr. 49: 1095-107.

Sundbäck K, Miles A, Göransson E, 2000. Nitrogen fluxes, denitrification and the role of microphytobenthos in microtidal shallow-water sediments: an annual study. Mar. Ecol.-Prog. Ser. 200: 59-76.

Viaroli P, Bartoli M, Bondavalli C, Christian RR, Giordani G, Naldi M, 1996. Macrophyte communities and their impact on benthic fluxes of oxygen, sulphide and nutrients in shallow eutrophic environments. Hydrobiologia 329:105-119.

Wollast R, 1983. Interactions in estuaries and coastal waters, p. 385-407. In: B. Bolin and R.B. Cook (eds.), The Major biogeochemical cycles and their interactions. John Wiley \& Sons, Chichester.

Zilius M, 2011. Oxygen and nutrient exchange at the sedimentwater interface in the eutrophic boreal lagoon (Baltic Sea). $\mathrm{PhD}$ dissertation, Klaipeda University, Klaipeda.

Zilius M, Bartoli M, Daunys D, Pilkaityte R, Razinkovas A, (2012). Patterns of benthic oxygen uptake in a hypertrophic lagoon: spatial variability and controlling factors. Hydrobiologia (in press). 